\title{
GREEN CONCRETE UTILIZING ANDESITE AND RHYOLITE AGGREGATE
}

\author{
Mohamed Y. Elsheikh \\ Professor, Structural Engineering Department, \\ Faculty of Engineering, Mansoura University, Egypt
}

\author{
Ahmed A. Elshami \\ Housing and Building National Research Center (HBRC), Egypt \\ Ibrahim Abdel Mohsen* \\ Structure Engineering Department, Horus University in Egypt, Egypt \\ *Correspondence: Ibrahim.mohsen.91@hotmail.com
}

\begin{abstract}
The study focuses on using a new type of coarse aggregate (andesite and Rhyolite) to produce a Green high-strength-self-compacting concrete (GHSSCC).Thus, four trail mixes were caste for estimating the concrete materials and proportions, also twenty three mixes were caste with some variables.

Four types of aggregate were used (gravel, dolomite, andesite and Rhyolite) to show the effect of aggregate type on concrete properties. Four aggregate ratios were used $(1: 1,2: 1,3: 2,5: 2)$ to show the effect of aggregate ratio on the concrete properties. Pozzolanic material (silica fume) was used with $15 \%$ replacement of the cement, water cementatious ratio was (0.3), super plasticizer (viscocrete) was used with (3\%) of the cement. Ordinary Portland cement was used in all the mixes, with cement contents $(500) \mathrm{kg} / \mathrm{m}^{3}$.

Self compacting concrete tests (spread flow diameter, spread flow time, L-box, and $V$-funnel) were prepared on concrete on its fresh phase, hardened concrete tests (compression strength, splitting strength, bending strength, and Shemidet hammer) were prepared to identify the mechanical properties of concrete
\end{abstract}

Keywords: Green concrete, High-strength, self-compacting concretes, Andesite and Rhyolite Aggregate

Cite this Article: Mohamed Y. Elsheikh, Ahmed A. Elshami and Ibrahim Abdel Mohsen, Green Concrete Utilizing Andesite and Rhyolite Aggregate, International Journal of Civil Engineering and Technology, 11(7), 2020, pp. 1-15.

https://iaeme.com/Home/issue/IJCIET?Volume=11\&Issue=7 


\section{INTRODUCTION}

Concrete is the second most consumed material after water with nearly 25 billion tons produced annually [1].

High strength concrete (HSC) has been used in high-rise buildings and other structures because of its technical, architectural, and economical advantages over normal strength concrete (NSC). However, the need for sustainable constructions around the world, which aims to farther reduce the consumption of construction materials, requires higher-strength concretes to be introduced. Nowadays, ultra-high strength concrete (UHSC) with compressive strength higher than $120 \mathrm{MPa}$ has been available with the development of concrete technology and the availability of variety of materials such as silica fume and high-range water-reducing admixtures $[2,3]$.

The Ultra-High-performance Concrete (UHPC) as a cementotious material with a minimum unconfined compressive strength of $150 \mathrm{MPa}$ was defined according to [4].

Nowadays, HSC is generally fabricated by the combination of low water to binder ratio (W/B) and high amount of cement. For sustainable application, the supplementary cementitious materials (SCM) containing pozzolanic materials, such as slag, fly ash , and silica fume, is widely used to improve the durability of the structure members at later times due to the pore refinement by the pozzolanic reaction [5].

Self-compacting concrete (SCC) is some of the most lucrative concrete technologies in recent years attracting the worldwide attention to not only fabricate sustainable structures with prolonged longevity but also reduce the environmental impacts of construction industry [6]. SCC is capable of flowing under its own weight without settlement, segregation, or bleeding and filling the remote corners. Therefore it is an appropriate structural material for structures with complex geometry or highly congested reinforcement $[7,8,9]$.

To produce SCC, concrete sophisticated stability since after casting into the place, segregation may occur, owing to the low viscosity and pseudo-plastic behavior of concrete [10], hence, superplasticizer (SP), viscosity modifying agent, and SCMs such as fly ash, GGBFS, and natural pozzolans are essential elements to reduce the water/binder ratio, increasing viscosity, and reducing the production cost of SCC [11]. SCC is another innovative type of concrete representing unprecedented technical characteristics in terms of high flow ability, resistance against segregation and bleeding, high strength, and filling capacity [12].

Self-compacting concrete (SCC) can flow through and fill the gaps of reinforcements, corners of molds and voids of rock blocks without any need for vibration and compaction during the placing process, which improves the overall efficiency of concrete construction projects[13]. SCC mixtures are usually designed with limiting aggregate contents, high volumes of paste, a lower water/powder ratio, large quantities of mineral fillers, and high rage water reducing admixtures [12].

The use of natural pozzolana in regular cement and SCC concrete mixtures has several advantages, including cost savings, reduction of hydration heat and reduction of $\mathrm{CO}_{2}$ emissions during the cement manufacturing [14]. The treated pozzolan then constitute a good substitute material for cement-based mortars. At 90-days and more, the concrete incorporating $30 \%$ pozzolan develops higher resistance than the control concrete [15]. They found that the direct resistance tests of lime-pozzolana pastes constitute a better resistance due to the pozzolanic reaction between lime and pozzolan $[16,17]$.

Natural stones are classified, such as metamorphic (marble, gneiss, etc.), sedimentary (limestone, travertine, etc.), or magmatic(granite, gabbro, basalt, andesite, etc.) according to their generation properties $[18,19]$. Egypt has an important place in the production of natural stone along the north-west of Hurghada along the western cost of the Red Sea as shown in 
Fig.(1). It is underlain mainly by the Dokhan Volcanics and both Older and Younger Granites. In these area, the Dokhan Volcanic rocks cover about $100 \mathrm{~km}^{2}$ including north of Gebel Dokhan along Wadi Um Sidra and further north along Wadi Um Asmer. The Dokhan volcanic successions are, rhyolites, quartz porphyry, ryodacites, andesite, decites, basalts and tuffaceous rocks, at three localities namely WadiZareib, Gebel Nugara and Wasif. [20].

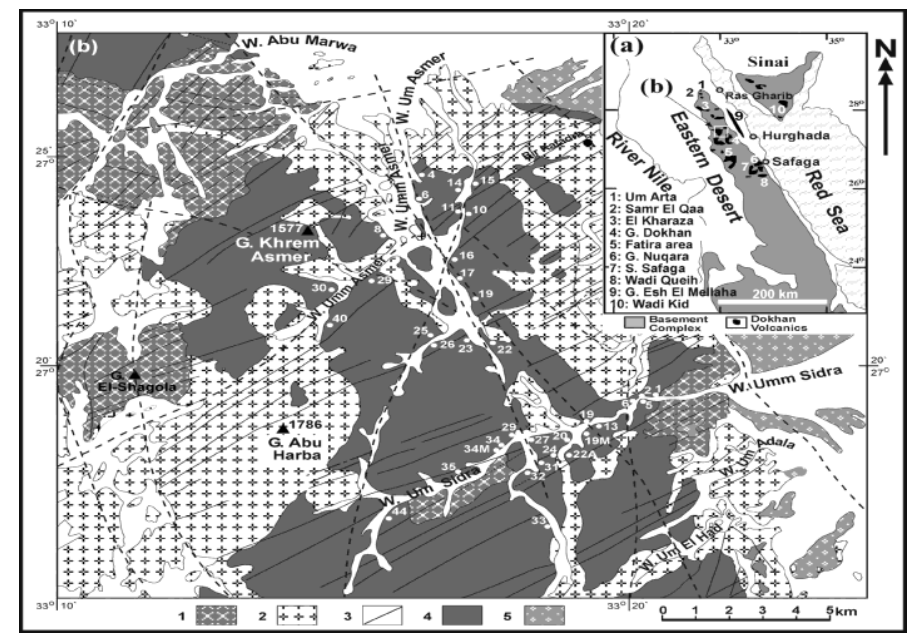

Figure 1 Dokhan Volcanic rocks in Egypt (Wadi Um Asmer, Wadi Um Sidra, Sinai).

Andesite is the name used for a family of fine-grained, extrusive igneous rocks that are usually light to dark gray in color. It is rich in Plagioclase feldspar minerals and may contain biotite, pyroxen, or amphibole. Andesite usually does not contain quartz or olivine. It contains $\mathrm{SiO}_{2}$ as the main component. Therefore, andesite may have pozzolanicity and thus may be used as mineral additive in concrete. It is moderate in its silica content. That is, it is neither rich nor deficient in this mineral, the silica content is $50-65 \%$, the density of this type of rocks is $2.11-2.36 \mathrm{gm} / \mathrm{cm}^{3}$, the specific gravity of the rock is $2.5-2.8$, It generally occurs in the hues of gray. However, it is lighter in color that basalt, It is said to form thicker fluxes or dome-shaped structures. [21].

Andesite start volcanoes are found above subduction zones in Central America, Mexico, Washington, Oregon, The Aleutian Arc, Japan, Indonesia, The Philippines, the Caribbean, and New Zealand, among other locations [22,23].

However, Rhyolite is an extrusive igneous rock with a very high silica content. It is usually pink or gray in color with grains so small that they are difficult to observe without a hand lens. Rhyolite is made of quartz, Plagioclase and sanidine, with minor amounts of hornblende and biotite. Many Rhyolites form from granitic magma that has rapidly that has partially called in the subsurface. Eruptions of granitic magma can produce Rhyolite, pumice, obsidian, or tuff. These rocks have similar compositions but different cooling conditions. Granitic magmas are rich in silica and often contain up to several percent gas by weight.

\section{EXPERIMENTAL PLAN}

\subsection{Scheme of Experimental Work}

Three groups of high-strength-self compacting concrete (GHSSCC), and normal strength concrete (NSC), $\left(\mathrm{f}_{\mathrm{c}}=50\right.$ to $\left.110 \mathrm{MPa}\right)$ with a total number of 23 mixes were prepared and investigated to satisfy the main objectives of the research, beside the four trial mixes to investigate the materials and their proportions. Table. 1 shows a general survey of these groups and the used materials, Ordinary Portland cement (OPC) was used in all the 23 mixes. The cement content $=500 \mathrm{Kg} / \mathrm{m}^{3}$ and water cementitious ratio $=0.3, \mathrm{~A}$ and is normal strength 
concrete (NSC) without any admixtures, while groups B, C, are high-strength-selfcompacting concrete (GHSSCC) using silica fume and viscocrete. Gravel, Dolomite, Andesite, Rhyolite were used as coarse aggregate with different ratios.

Table 1 General Survey of the Materials used.

\begin{tabular}{|l|c|c|c|}
\hline \multicolumn{1}{|c|}{ Mixes } & \multicolumn{3}{|c|}{$\mathbf{2 3}$} \\
\hline Group & $\begin{array}{c}\text { A } \\
\text { (NSC) }\end{array}$ & B (GHSSCC) & C (GHSSCC) \\
\hline $\begin{array}{l}\text { Aggregate } \\
\text { Type }\end{array}$ & $\begin{array}{c}\text { Gravel } \\
\text { Dolomite } \\
\text { Andesite } \\
\text { Rhyolite }\end{array}$ & $\begin{array}{c}\text { Gravel } \\
\text { Dolomite } \\
\text { Andesite } \\
\text { Rhyolite }\end{array}$ & $\begin{array}{c}\text { Andesite and } \\
\text { Rhyolite with } \\
\text { different ratio }\end{array}$ \\
\hline $\begin{array}{l}\text { Aggregate } \\
\text { Ratio }\end{array}$ & $2: 1$ & $\begin{array}{c}2: 1 \quad 1: 1 \\
3: 2\end{array}$ & $\begin{array}{c}1: 1: 1 \quad 1: 2: 1 \\
1: 1: 2\end{array}$ \\
\hline $\begin{array}{l}\text { Cement } \\
\text { content }\end{array}$ & $500 \mathrm{Kg} / \mathrm{m} 3$ & $500 \mathrm{Kg} / \mathrm{m} 3$ & 500 \\
\hline W/Wcm & 0.3 & 0.3 & $\mathrm{Kg} / \mathrm{m} 3$ \\
\hline Silica fume & - & $15 \%$ & $15 \%$ \\
\hline Viscocrete & - & $3 \%$ & $3 \%$ \\
\hline
\end{tabular}

\subsection{Materials}

\subsubsection{Fine Aggregate}

A natural sand with fineness modulus of 3.00, specific gravity of 2.65 and unit weight of 1750 $\mathrm{Kg} / \mathrm{m}^{3}$ was used in this research.

\subsubsection{Coarse Aggregate}

Four types of aggregates were used in this research. These types are Gravel, Dolomite, Andesite and Rhyolite.

Table 2 Main properties of aggregates.

\begin{tabular}{|l|c|c|c|}
\hline \multicolumn{1}{|c|}{ Type } & $\begin{array}{c}\text { Specific } \\
\text { Gravity }\end{array}$ & $\begin{array}{c}\text { Water } \\
\text { Absorption } \\
(\boldsymbol{\%})\end{array}$ & $\begin{array}{c}\text { Crushing } \\
\text { value } \\
(\boldsymbol{\%})\end{array}$ \\
\hline Sand & 2.65 & ----- & ----- \\
\hline Gravel & 2.65 & 0.52 & 32 \\
\hline Dolomite & 2.6 & 0.55 & 28 \\
\hline Andesite & 2.54 & 0.63 & 22 \\
\hline Rhyolite & 2.68 & 0.66 & 20 \\
\hline
\end{tabular}




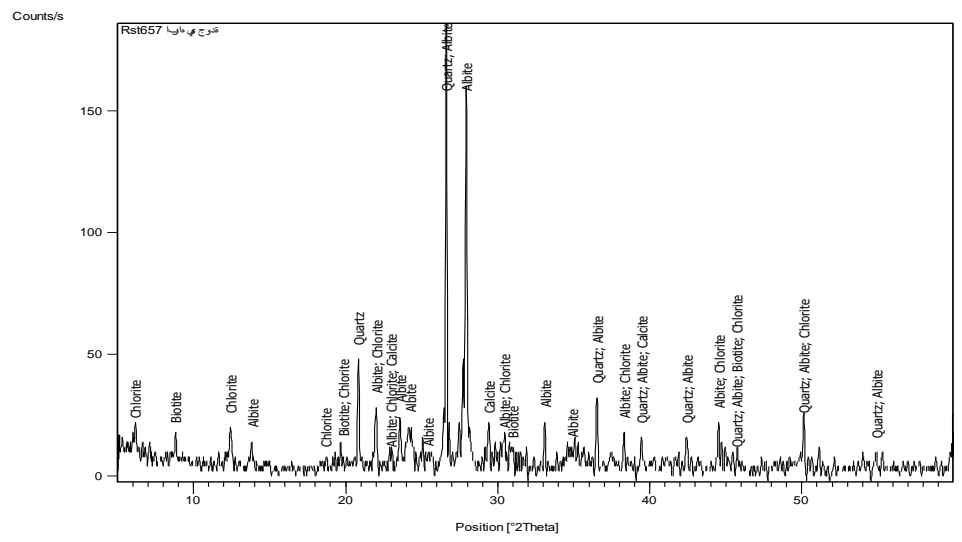

Figure 2 X-ray diffraction for rhyolite rock

\subsubsection{Cement}

One type of cement was used in this study (Ordinary Portland cement) of Sinai Company, with a physical properties, Specific gravity $=3.15$, Initial setting time $=75 \mathrm{~min}$ and final initial time $=4 \mathrm{hr}$.

\subsubsection{Silica fume}

This material is highly Pozzolanic and reacts very quickly with calcium hydroxide caused by the hydration of the cement to form high strength calcium silicate hydrates $\mathrm{C}-\mathrm{S}-\mathrm{H}$, the main problem of using silica fume is that it increases the water demand unless super plasticizer is used.

\subsubsection{Super plasticizer (Viscocrete-3435)}

Using the viscocrete-3425 also improve the flowability (resulting highly reduced placing and compacting efforts, improve creep and shrinkage behavior, reduced the rate of carbonation of concrete, improve the water impermeability, and it does not affect the steel reinforcement, its density is $1.08 \mathrm{gm} / \mathrm{cm}^{3}$.

\subsubsection{Water/ Cementitious Materials ratio}

Clean water was used and water/ cementitious ratio of ( 0.3 and 0.22 ) was used to produce high-strength-self-compacting concrete (GHSSCC).

\subsection{Tests and Specimens}

- Compression test after 7, 28, and 56 days was carried out on ;

- $100 \mathrm{~mm}$ cubes

- Splitting test after 7, 28, and 56 days was carried out:

- $150 \times 300 \mathrm{~mm}$ cylinders

- Flexural strength test after 7,28, and 56 days was carried out;

- $100 \times 100 \times 500 \mathrm{~mm}$ prisms

\subsection{Tests of Fresh Concrete}

Three tests of fresh concrete were carried out check to properties of SCC (filling ability, passing ability (free from blocking at reinforcement) and its resistance to segregation (stability): 
- slump flow test and $t_{50}$ test.

- V-funnel test.

- and L-box test.

\subsection{Tests of Hardened Concrete}

Four tests were performed on the concrete on its hardened phase :

- Compression strength

- Splitting Tensile Strength

- Flexural (Bending) Strength

- Schemidet Hummer

\section{RESULTS AND DISCUSSION}

\subsection{Fresh Concrete}

G: gravel

D : dolomite
A : andesite
$\mathrm{R}$ : Rhyolite

Table 3

\begin{tabular}{|l|l|}
\hline Cement content & $500 \quad \mathrm{~kg} / \mathrm{m} 3$ \\
\hline $\mathrm{W}_{\mathrm{w}} / \mathrm{W}_{\mathrm{cm}}$ & 0.3 \\
\hline Silica fume & $15 \%$ \\
\hline Viscocrete & $3 \%$ \\
\hline
\end{tabular}

\subsubsection{Spread Flow Diameter}

As the diameter increases, the flow ability of fresh SCC increases. Thus the best aggregate type for flow ability is respectively (gravel, andesite, dolomite and rhyolite as shown in Fig.(3), may be its due to the rounded shape with a smooth surface texture of the gravel unlike the angular shape with a roughness surface texture of the crushed stone and volcanic rocks, or due to the high water absorption ratio of the crushed stone and volcanic rocks compared with the gravel.

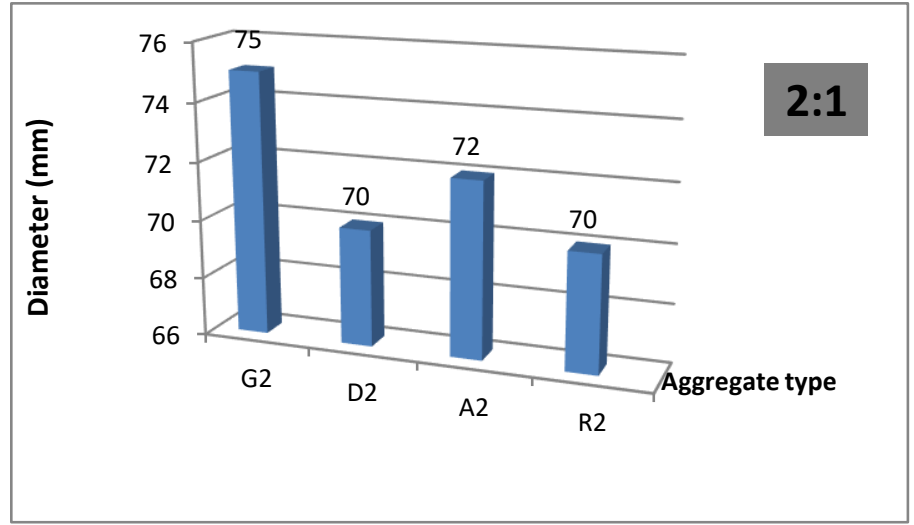

Figure 3 The spread flow diameter of four mixses with different aggregate types at aggregate ratio 2:1 


\subsubsection{Spread Flow Time}

As the time decreases, the flow ability of fresh SCC increases. Thus the best aggregate type for flow ability is respectively (gravel, dolomite, andesite and rhyolite as shown in Fig.(4), may be its due to the rounded shape with a smooth surface texture of the gravel unlike the angular shape with a roughness surface texture of the crushed stone and volcanic rocks, or due to the high water absorption ratio of the crushed stone and volcanic rocks compared with the gravel.

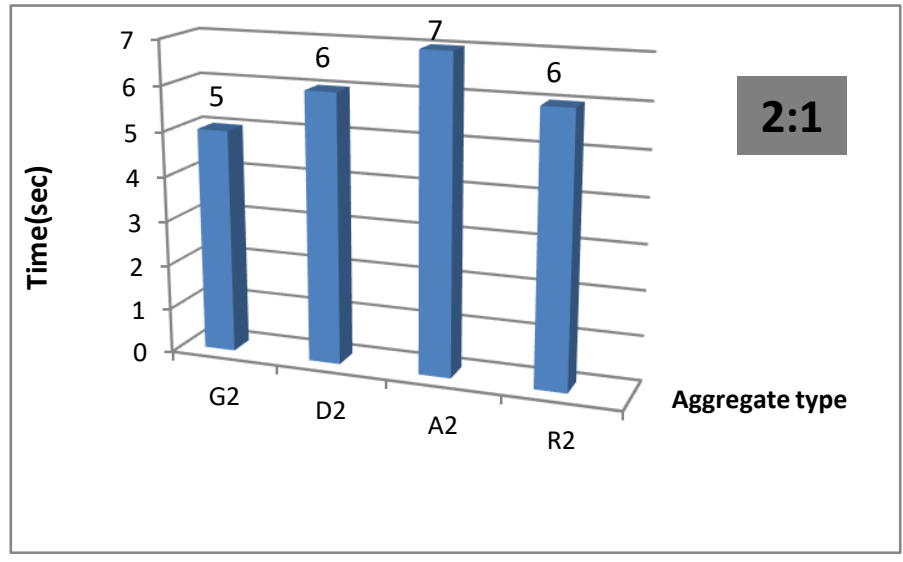

Figure 4 The spread flow time (T500) of four mixses with different aggregate types at aggregate ratio $2: 1$

\subsubsection{Passing Ability}

As the ratio of $\mathrm{h} 2 / \mathrm{h} 1$ increases, the passing ability of fresh SCC increases. Thus the best aggregate type for flow ability is respectively (gravel, dolomite, rhyolite and andesite as shown in Fig.(5), may be its due to the rounded shape with a smooth surface texture of the gravel unlike the angular shape with a roughness surface texture of the crushed stone and volcanic rocks, or due to the high water absorption ratio of the crushed stone and volcanic rocks compared with the gravel.

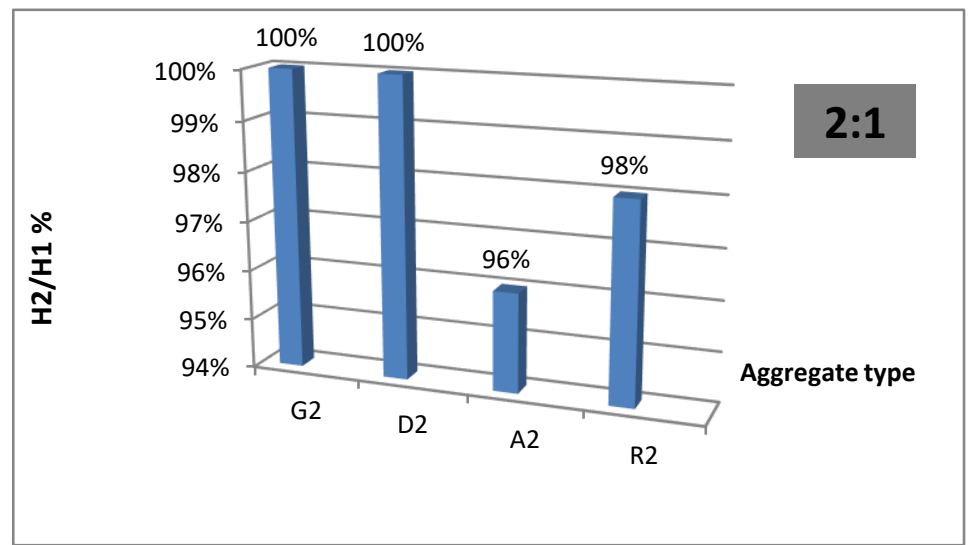

Figure 5 The passing ability (h2/h1) of four mixses with different aggregate type at aggregate ratio 2 :

\subsubsection{V-Funnel Time}

As the time decreases, the flow ability of fresh SCC increases. Thus the best aggregate type for flow ability is respectively (gravel, dolomite, rhyolite and andesite as shown in Fig.(6), may be its due to the rounded shape with a smooth surface texture of the gravel unlike the 
angular shape with a roughness surface texture of the crushed stone and volcanic rocks, or due to the high water absorption ratio of the crushed stone and volcanic rocks compared with the gravel.

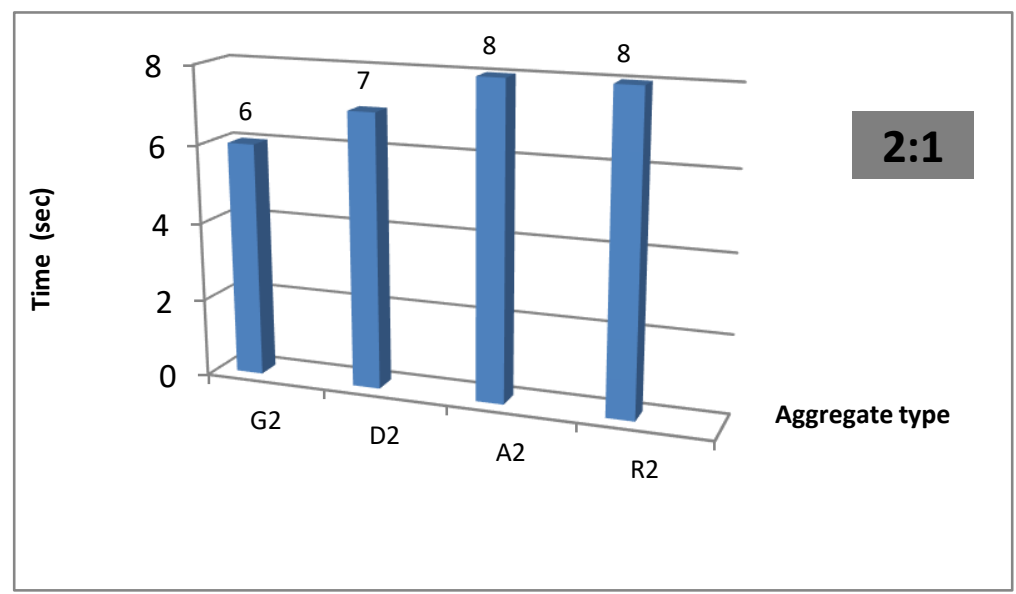

Figure 6 The V-funnel (T0) of four mixses with different aggregate types at aggregate ratio $2: 1$

\subsection{Hardened Concrete}

\subsubsection{Effect of Aggregate Type}

As shown in Fig.(7), the compressive strength increases using rhyolite, dolomite, andesite and gravel respectively as a coarse aggregate in concrete, may be its due to the low crushing valued ratio of rhyolite as shown in table.(2).

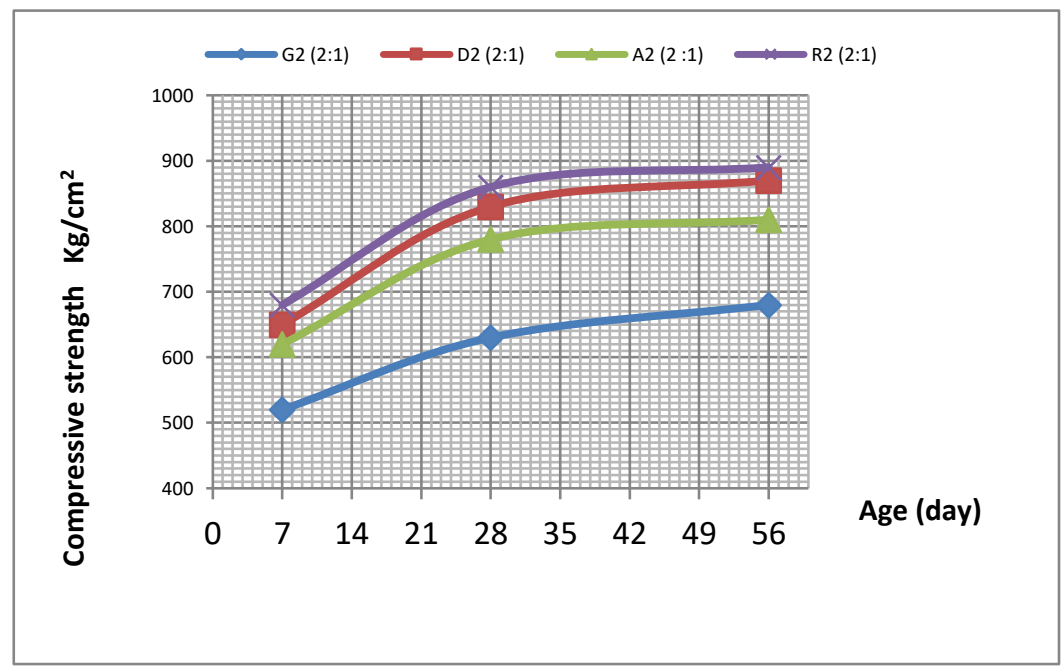

Figure 7 Relationship between the compressive strength and the age showing the aggregate types at aggregate ratio $2: 1$

As shown in Fig.(8), the splitting strength increases using dolomite, rhyolite, andesite and gravel respectively as a coarse aggregate in concrete, may be its due to the angular shape with a roughness surface texture of dolomite which increases the bond between concrete constituents. 
Mohamed Y. Elsheikh, Ahmed A. Elshami and Ibrahim Abdel Mohsen

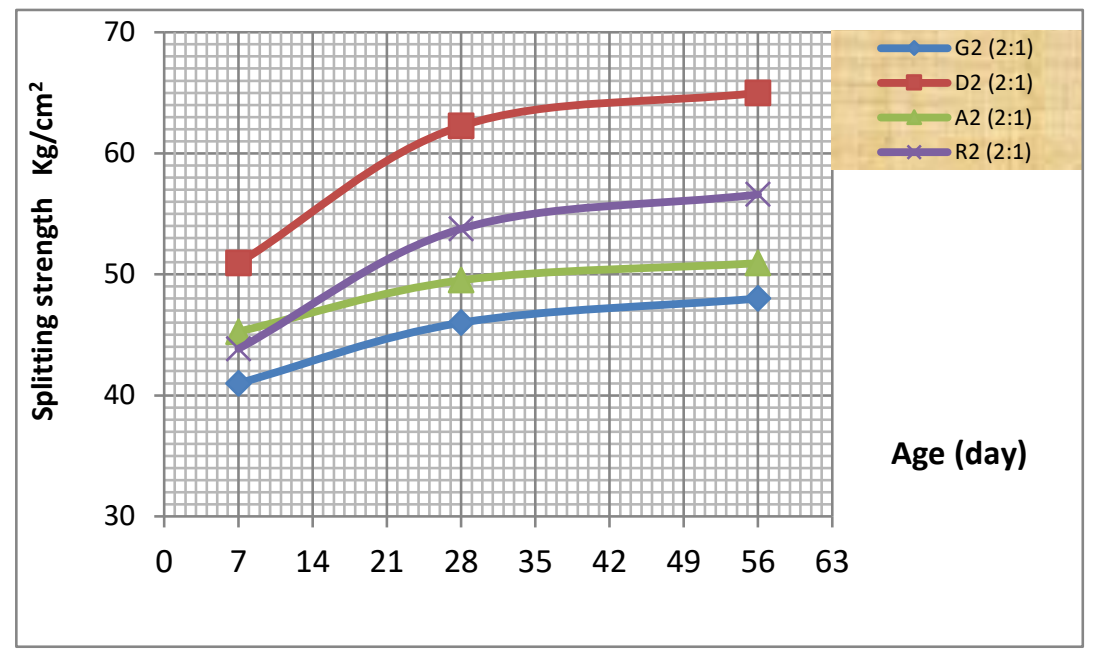

Figure 8 Relationship between the splitting strength and the age showing the aggregate types at aggregate ratio $2: 1$

As shown in Fig.(9), the bending strength increases using rhyolite, dolomite, andesite and gravel respectively as a coarse aggregate in concrete, may be its due to the low crushing valued ratio of rhyolite as shown in table.(2).

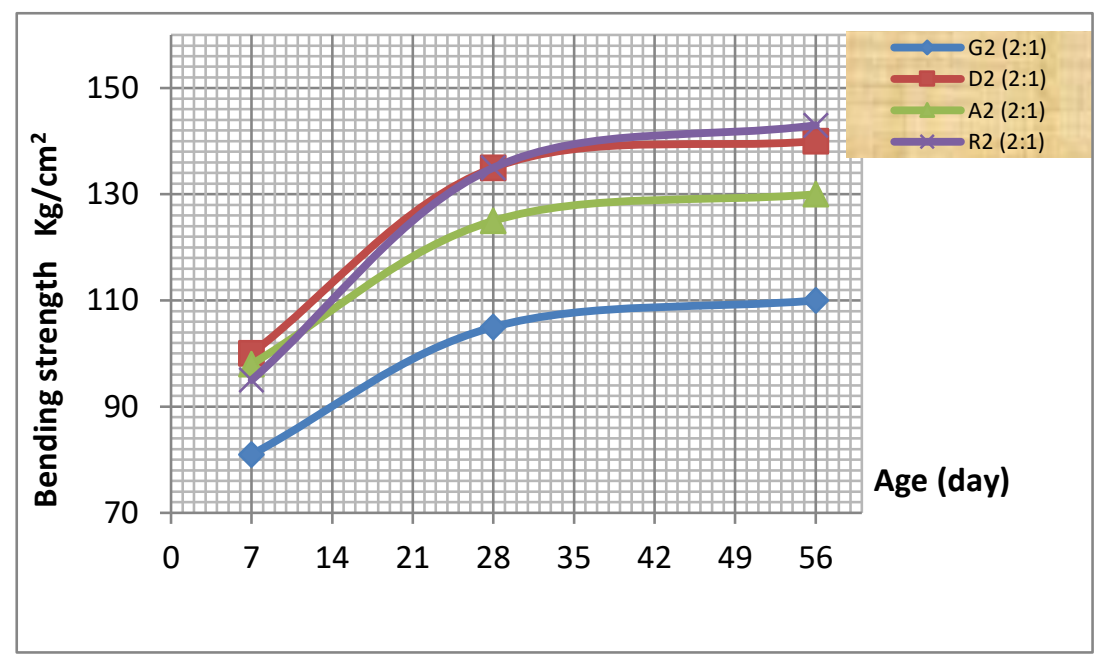

Figure 9 Relationship between the bending strength and the age showing the aggregate types at aggregate ratio $2: 1$

As shown in Fig.(10), the schemidet hummer results are not reliable, the error ranged from (40 to 50$) \%$, so the hummer needed to be calibrated. 
Green Concrete Utilizing Andesite and Rhyolite Aggregate

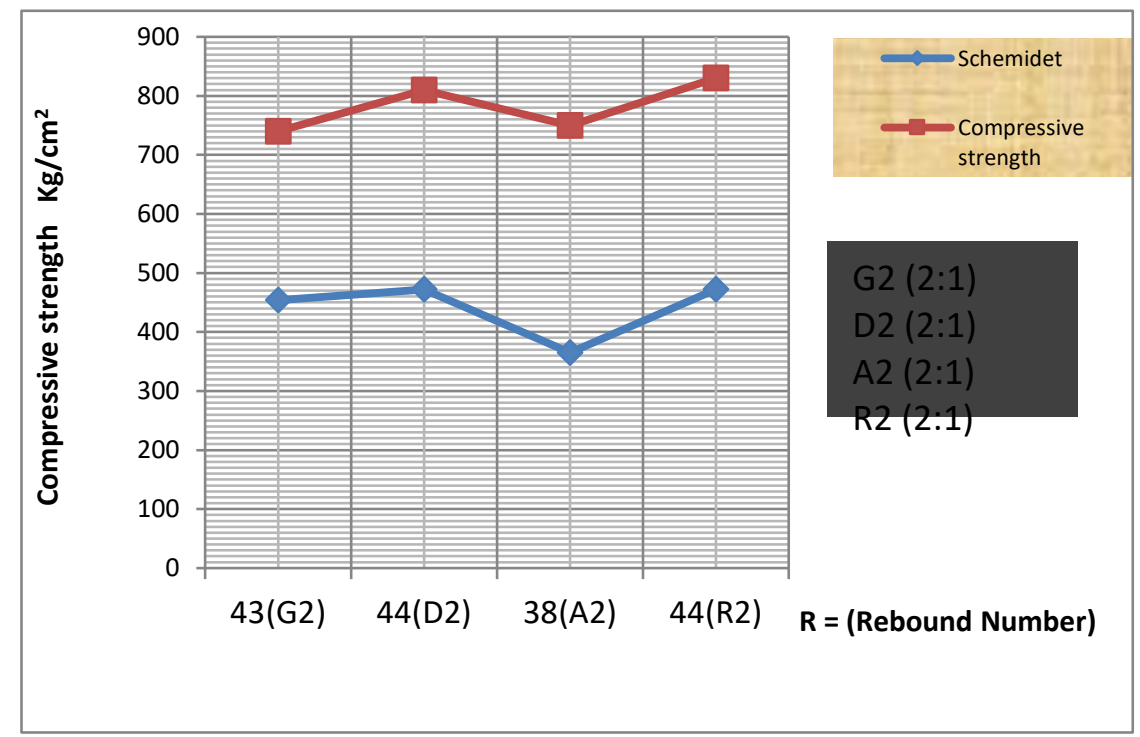

Figure 10 Relationship between compressive and Schemidet strength showing the rebound number at aggregate ratio 2: 1

\subsubsection{The Effect of Aggregate Ratio (at cement content $=500 \mathrm{~kg} / \mathrm{m}^{3}$ )}

As shown in Fig.(11), the compressive strength increases using the andesite ratio (2:1), (3:2), $(5: 2)$ and (1:1) respectively as a coarse aggregate in concrete, because both the aggregate and the cement paste share the stresses and the failure may occurred through the aggregate or the cement paste.

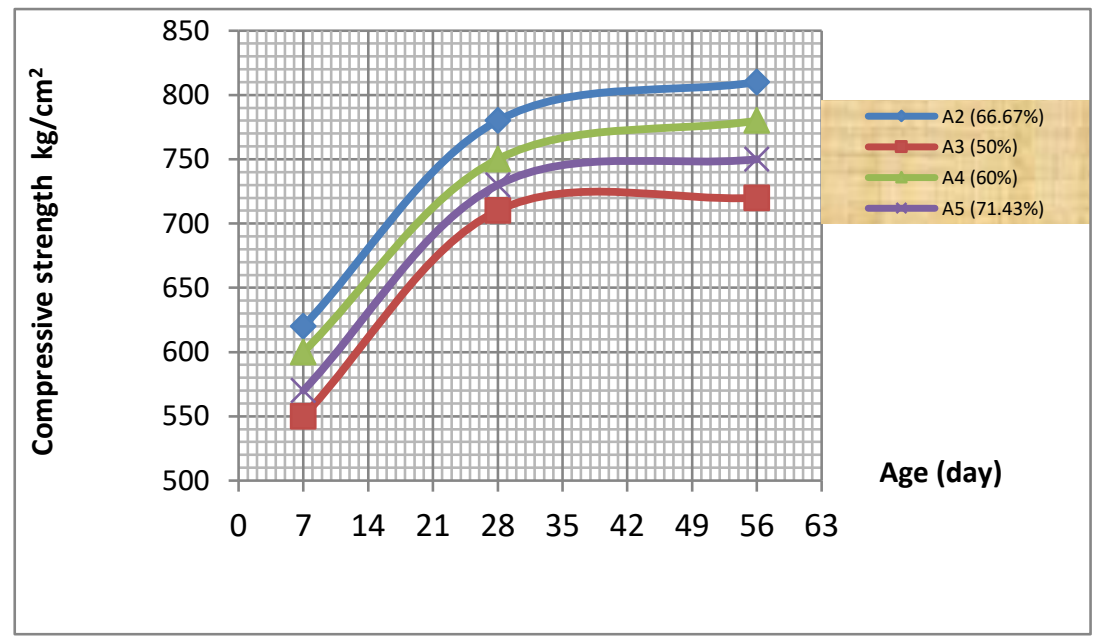

Figure 11 Relationship between compressive strength and the age showing the effect of andesite ratio at cement content $=500 \mathrm{~kg} / \mathrm{m}^{3}$

As shown in Fig.(12), the splitting strength increases using the andesite ratio (2:1), (3:2), (5:2) and (1:1) respectively as a coarse aggregate in concrete, because both the aggregate and the cement paste share the stresses and the failure may occurred through the aggregate or the cement paste. 
Mohamed Y. Elsheikh, Ahmed A. Elshami and Ibrahim Abdel Mohsen

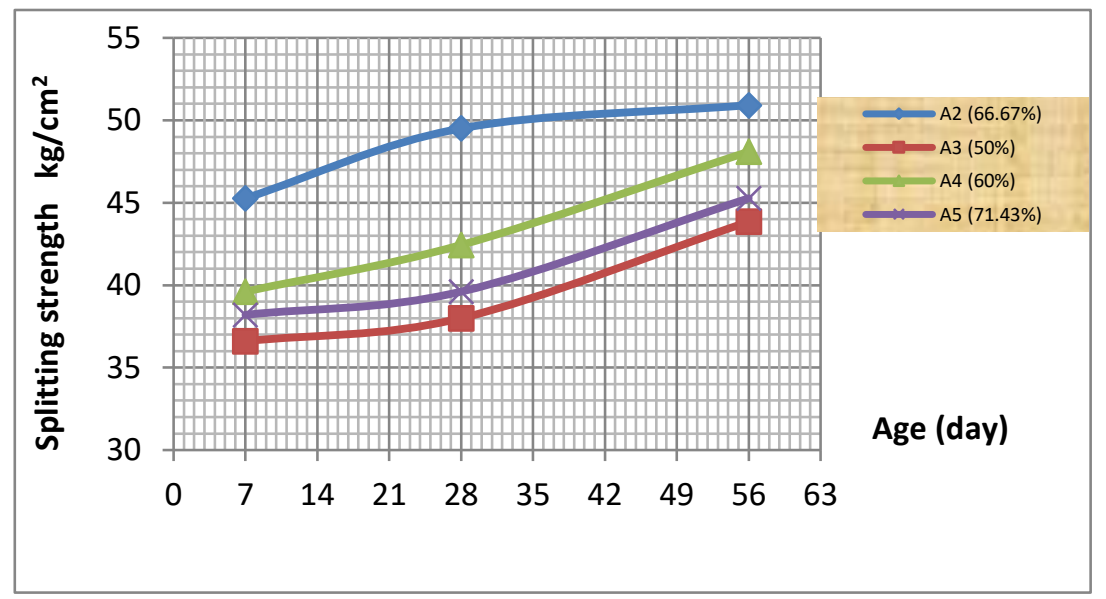

Figure 12 Relationship between splitting trength and the age showing the effect of andesite ratio at cement content $=500 \mathrm{~kg} / \mathrm{m}^{3}$

As shown in Fig.(13), the bending strength increases using the andesite ratio (2:1), (3:2), $(5: 2)$ and (1:1) respectively as a coarse aggregate in concrete, because both the aggregate and the cement paste share the stresses and the failure may occurred through the aggregate or the cement paste.

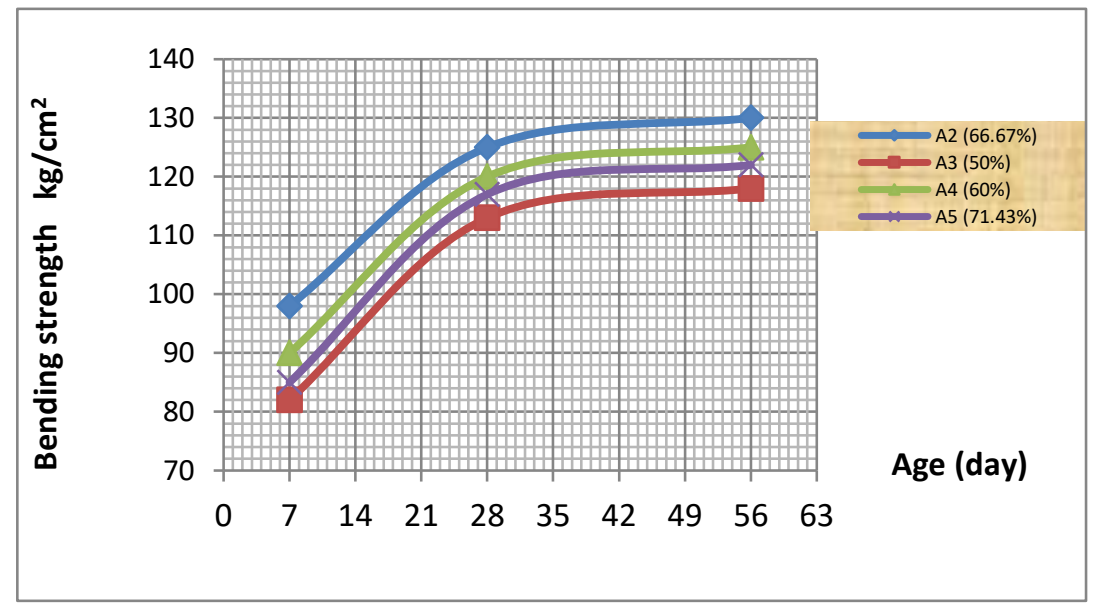

Figure 13 Relationship between bending strength and the age showing the effect of andesite ratio at cement content $=500 \mathrm{~kg} / \mathrm{m}^{3}$

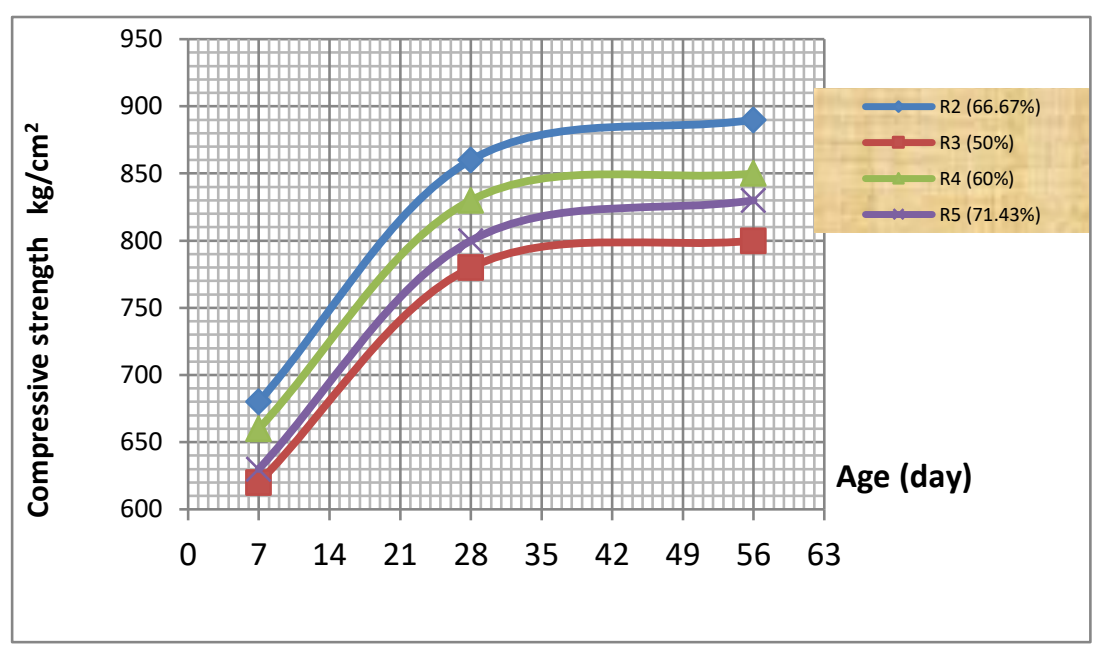

Figure 14 Relationship between compressive strength and the age showing the effect of Rhyolite ratio at cement content $=500 \mathrm{~kg} / \mathrm{m}^{3}$ 
As shown in Fig.(14), the compressive strength increases using the rhyolite ratio (2:1), $(3: 2),(5: 2)$ and $(1: 1)$ respectively as a coarse aggregate in concrete, because both the aggregate and the cement paste share the stresses and the failure may occurred through the aggregate or the cement paste.

As shown in Fig.(15), the splitting strength increases using the rhyolite ratio (2:1), (3:2), (5:2) and (1:1) respectively as a coarse aggregate in concrete, because both the aggregate and the cement paste share the stresses and the failure may occurred through the aggregate or the cement paste.

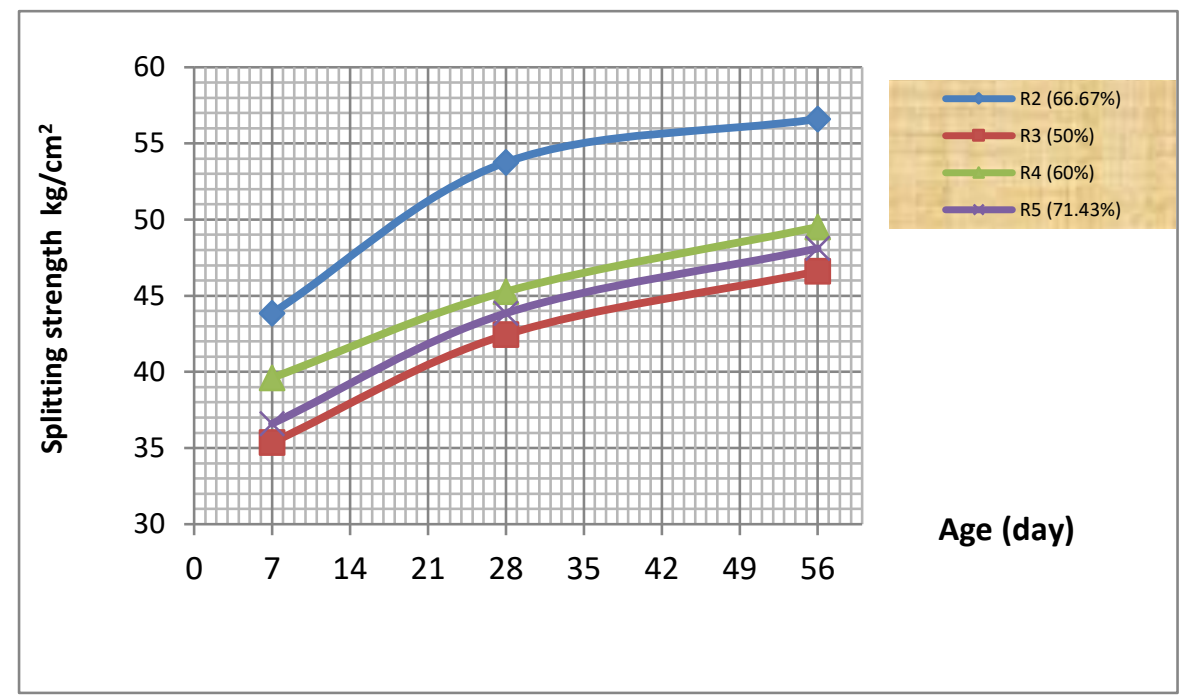

Figure 15 Relationship between splitting strength and the age showing the effect of Rhyolite ratio at cement content $=500 \mathrm{~kg} / \mathrm{m}^{3}$

As shown in Fig.(16), the bending strength increases using the rhyolite ratio (2:1), (3:2), $(5: 2)$ and (1:1) respectively as a coarse aggregate in concrete, because both the aggregate and the cement paste share the stresses and the failure may occurred through the aggregate or the cement paste.

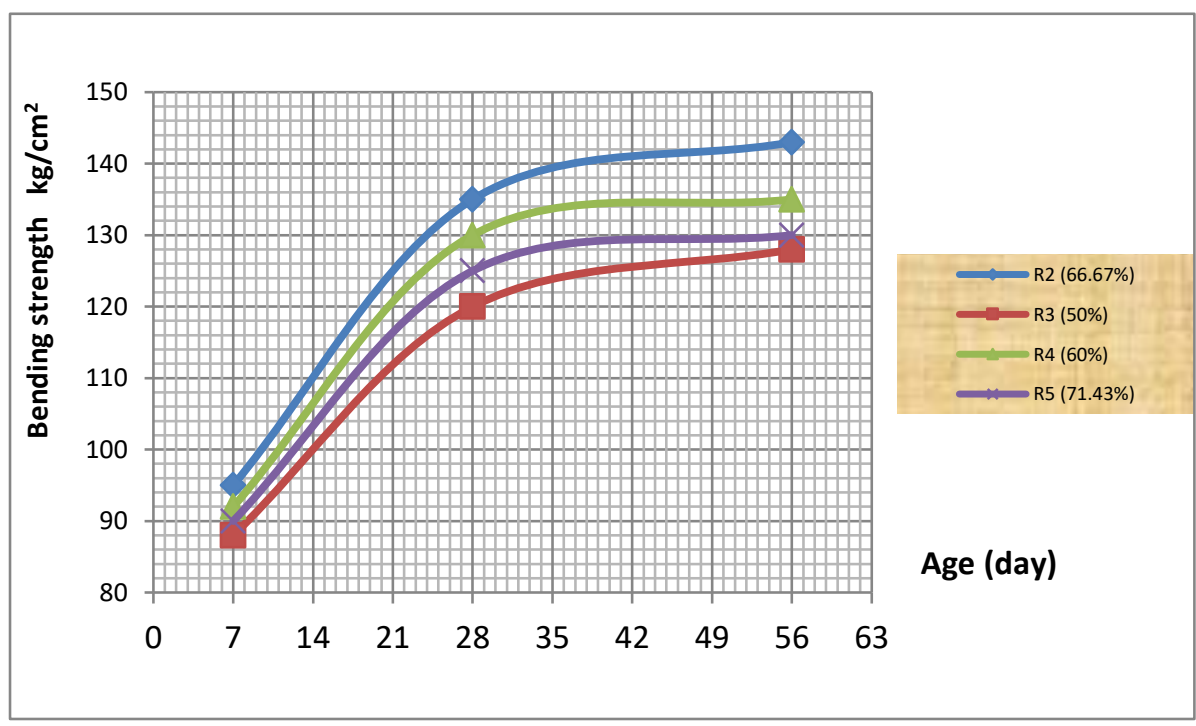

Figure 16 Relationship between bending strength and the age showing the effect of Rhyolite ratios at cement content $=500 \mathrm{~kg} / \mathrm{m}^{3}$ 


\subsection{Scanning Electronic Microscope (SEM) Examinations R2}

Scanning electron microscopy was carried out in faculty of agriculture at Mansoura University for concrete samples using electronic microscope type JEOL JSM-651OLV, of magnification 5000 and 6500 as shown in Fig. 17

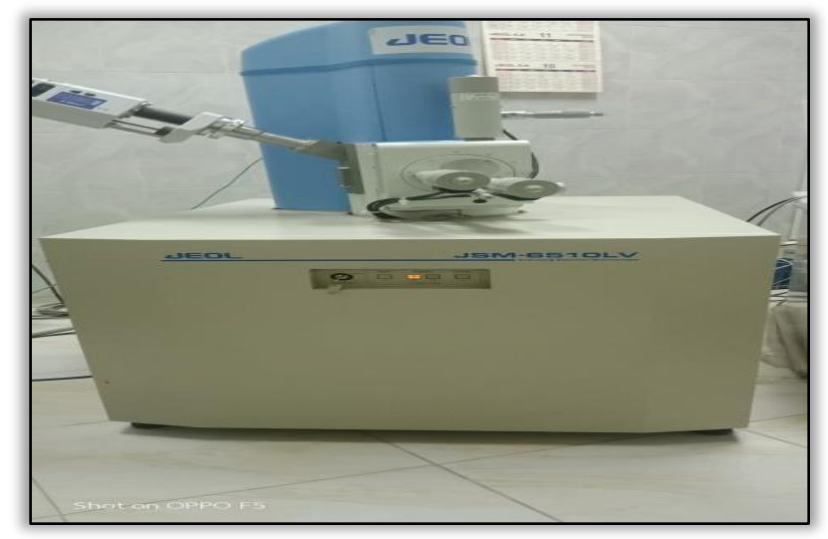

Figure 17 The electronic microscope machine

SEM technique has been adopted to recognize the extent of the CSH formation, i.e. the extent of the hydration process, Fig. (18) shows that moderate effect on the compressive strength and no cracking is evident, i.e. a moderate calcium silicate hydrate CSH formation.
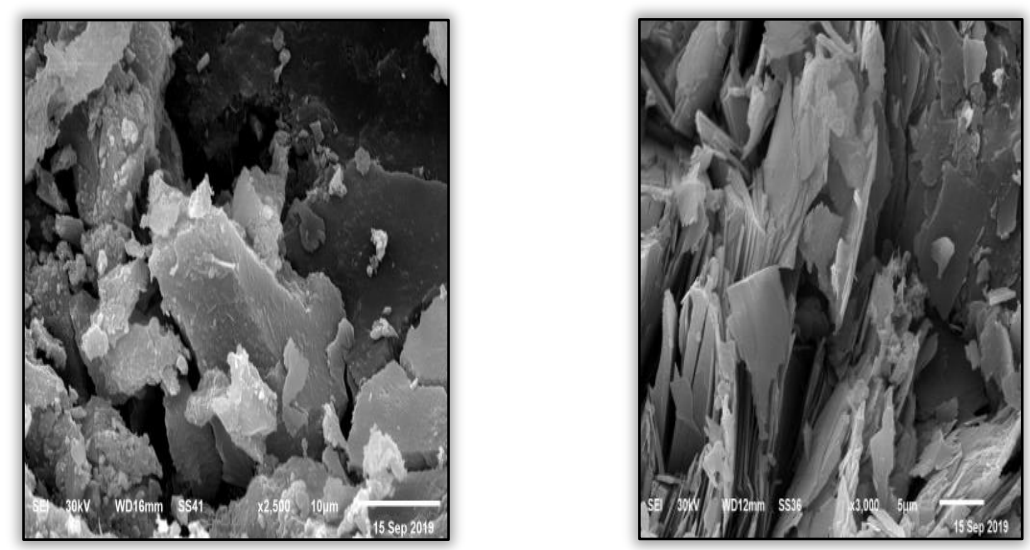

Figure 18 SEM for Mix R2

\section{CONCLUSIONS}

- Using the gravel as coarse aggregate provides more workability, filling ability and passing ability more than using crushed stone and volcanic rocks in concrete.

- Crushed stone and volcanic rocks need more water than the gravel to achieve the fresh properties of SCC.

- As the Aggregate ratio increases the properties of fresh SCC decreases.

- Using the crushed stone (Dolomite) and the volcanic rocks (Andesite and Rhyolite) as a coarse aggregate in GHSSCC, affect the compression strength positively.

- The sharp angular shape and the roughness surface area of the crushed stone and volcanic rocks provide a higher compressive strength for concrete.

- Using the crushed stone (dolomite) and the volcanic rocks as coarse aggregate in NSC have no effect on the compressive strength of concrete. 
- Using gravel as coarse aggregate in NSC does not affect the strength.

- The rounded shape and the smooth surface area of the gravel may negatively affect the concrete strength.

- Using the crushed stone (dolomite) and volcanic rocks (Andesite and Rhyolite) as a coarse aggregate in GHSSCC, enhancing the splitting and bending strength of concrete.

- Using gravel as coarse aggregate in GHSSCC, affect the splitting strength and bending strength negatively.

- The error at Schemidet hummer results about (40 to 50) \% different of using the compressive strength machine results (cement content $=500 \mathrm{~kg} / \mathrm{m}^{3}$ ).

- The best aggregate ratio of crushed stone and volcanic rocks of GHSSCC (cement content $\left.=500 \mathrm{~kg} / \mathrm{m}^{3}\right)$ is $2: 1(66.67 \%)$.

\section{REFERENCES}

[1] Brett Williams, William Heard, Steven Graham, Xu Nie, Effect of specimen geometry on triaxial compressive response of high-strength concrete, Research and Development Center, 3909 Halls Ferry Rd, Vicksburg, MS 39180,USA, 3, Feb, 2020.

[2] Ming-Xiang Xiong, J.Y. Richard Liew, Mechanical behavior of ultra-high strength concrete at elevated temperatures and fire resistance of ultra-high strength concrete filled steel tubes, School of Civil and Transportation Engineering, Guangdong University of Technology, 100 Waihuan Xi Road, GuangZhou, China 510006, (2016).

[3] European Committee for standardization (CEN). EN 1994-1-2 Eurocode 4: design of composite steel concrete structures - Part 1-2: General rules- Structural fire design, Brussles, 2005.]

[4] ACI Committee, in: 239R-18: Ultra-High-Performance Concrete: An Emerging Technology Report, 2018, pp. 1-5.

[5] Amnadmua, K., Tangchirapat, W., jaturapitakkul, C., "'Strength, Water Permeability, and Heat Evaluation of High strength Concrete Made from the Mixture of Calcium Carbide Residue and Fly Ash', Des. 2013, pp. 894-901.

[6] F. Rodrigues, I. Joekes, Cement industry: sustainability, challenges and perspectives, Environ. Chem. Lett. 9 (2) (2011) 151-166.

[7] K. Khayat, K. Manai, A. Trusel, In situ mechanical properties of wall elements cast using self- consolidating concrete, ACI Mater. J. 94 (1997) 491-500.

[8] F. Aslani, Z. Asif, Properties of ambient-cured normal and heavyweight geopolymer concrete exposed to high temperatures, Materials 12 (5) (2019), 740.

[9] F. Valizadeh, F. Aslani, Z. Asif, M. Roso, Development of heavyweight self-compacting concrete and ambient-cured heavyweight geopolymer concrete using magnetite aggregates, Materials 12 (7) (2019) 1035.].

[10] K.H Khayat, Workability, testing and performance of self-consolidating concrete, Mater. J. 96 (3) (1999), 346-353.

[11] M. Sahmaran, I.O. Yaman, Hybrid Fiber reinforced self-compacting concrete with a highvolume coarse fly ash, Constr. Build. Mater.21 (1), (2007), 150-56.

[12] H. Okamoura, M. Ouchi, Self-compacting concrete, J. Adv. Concr. Technol. 1 (1) (2003) 5-15., Farhad Aslani, Fatemeh Hamidi, Afsaneh Valizadeh, Anthony Thanh, High.

[13] X. An, Q. Wu, F. Jin, Rock-filled concrete, the new norm of SCC in hydraulic engineering in China, Cem. Concr. Compos.54 (2014), 89-99.]. 
[14] G. Habert, N. Choupay, J.M. Montel, D. Guillaume, G, Escadeillas, Effects of the secondary minerals of the natural pozzolans on their pozzolanic activity, Cem. Concr. Res. 38 (2008), 963-975.].

[15] M. Mouli, H. Khelafi, Performance characteristics of light weight aggregate concrete containing natural pozzolan, Build. Environ. 43 (2008), 31-36.

[16] B. Uzal, L. Turanli, H. Yucel, M.C. Goncuoglu, A. Culfaz, Pozzolanic activity of clinoptilolite: a comparative study with silica fume, fly ash and non-zeolitic natural pozzolan, Cem. Cocor. Res. 40 (2010), 398-404.

[17] M. Omrane, M. Rabehi, Effect of natural pozzolan and recycled concrete aggregates on thermal and physic-mechanical characteristics of self-compacting concrete, Civil Engineering Department, University of Djelfa, Algeria, 2020.

[18] A. Karakus, Investigation on possible use of Diyarbakir basalt waste in stone asphalt, Constr. Build. Mater. 25 (2011), 3502-3507.

[19] K.E. Alyamac, R. Ince, A preliminary concrete mix design for SCC with marble powders, Conctr. Build. Mater. 23 (2009), 1201-1210.

[20] I. Gouda, High Strength Self Compacting Concrete Utilizing Andesite and Ryolite Aggregate, Structural Engineering Department, Faculty of Engineering, Mansoura University, (2016), 53-55.

[21] Metin Davraz, Hakan Cetlan, Tayfun Ungunoglu, Pozzolanic effect of andesite waste powder on mechanical properties of high strength concrete, National and Industrial Building Materials Applications and research Center, Turkey, 2018.

[22] Hobart King, “Igneous Andesite Rock”, www.Geology.com, June, 2015.

[23] "Properties of Andesite”, www.Buzzle.com/articles/properties-and-uses-ofandesiterock.html. 